\title{
The Impact of Teaching by Using STEM Approach in The Development of Creative Thinking and Mathematical Achievement Among the Students of The Fourth Scientific Class
}

\author{
https://doi.org/10.3991/ijim.v15i13.24185 \\ Lina Fouad Jawad $\left.{ }^{(}\right)$, Ban Hassan Majeed \\ University of Baghdad, Baghdad, Iraq \\ Lina.f.j@ihcoedu.uobaghdad.edu.iq \\ Haider Th. Salim ALRikabi \\ Wasit University, Wasit, Iraq
}

\begin{abstract}
The research aims to know the impact of science, technology, engineering, and mathematics education on both creative thinking and mathematical achievement. To achieve it, the two researchers followed the quasi-experimental approach with an experimental design for two groups, one experimental and the other a control. The research sample consisted of (32) female students from the fourth scientific grade in Al-Intisar Preparatory School for Girls/ AlRasafa, First Directorate. The sample was chosen intentionally and was divided into two groups: a control group studying by the traditional method, their number (16), and an experimental group that applied the STEM approach, their number also (16). There was parity between the two research groups in the variables (chronological age, previous achievement in mathematics, innovative thinking). The research tools consist of testing innovative thinking skills (fluency, flexibility, originality, relationships) and achievement tests. The research experiment was applied before and after. To test the validity of the hypotheses, data were collected and then statistically analyzed using appropriate statistical methods. The results of the research found that there were statistically significant differences in both the tests of innovative thinking and mathematical achievement in favor of the experimental group that studied according to the STEM approach, and in light of the results, the researchers recommended several recommendations and suggestions.
\end{abstract}

Keywords - STEM Introduction, Innovative Thinking, Mathematical Achievement

\section{Introduction}

Learning mathematics is one of the most important pillars of the teaching and learning process, especially in the current era in which mathematics has intertwined with the 
world of computing and programming[1, 2]. It has increased its importance and the importance of learning it, with the constant complaint of students about learning that subject, and their low mathematical achievement. It was imperative to seek modern and effective methods and approaches for teaching mathematics. Among these approaches, the Integrated Introduction to Science, Technology, Engineering and Mathematics, and its abbreviation (STEM). Where teaching by the (STEM) entrance works on the integration between the information acquired within mathematics as a central subject with other subjects, namely science, technology, engineering[3]. It creates an integrated knowledge that enables the student to understand mathematics more easily, helps him in solving mathematical problems, and designing innovative products in mathematics classes, where the numbers enter Mathematics and calculations and mathematical relations in the aforementioned subjects, thus mathematics is a starting point for students' learning and expanding their knowledge in the four disciplines, starting with. Within the scope of methods and curricula for teaching mathematics, many types of research and studies have been conducted to identify the importance of the STEM approach, its impact on mathematics learning and achievement[4]. Where it proved that the entrance has a positive effect on the achievement of science, mathematics, the development of thinking skills in general, including, for example, mathematical thinking, some creative thinking skills, conceptual comprehension, and life skills[5-10]. The mathematics in textbooks that students learn; is far from what students need in terms of mathematical knowledge in other subjects such as science[11]; because mathematics is the subject of the mind and thinking, the development of thinking skills, especially innovative thinking, is necessary to study mathematics, despite this, many studies have shown that there is a decline in the levels of innovative thinking among students, and accordingly, we need what helps the development of this thinking since the STEM approach is primarily based on research, investigation, experiment, innovation, it will surely help students develop their innovative thinking skills. In addition to what studies have proven, the two researchers see, based on their experience, that there is an urgent need to change a teaching entrance that helps the teacher and the student in teaching mathematics, attracts students, links between life and its problems, by using principles, theories, laws of mathematics, which is expected to happen with the application of the STEM entrance[12]. The research derives its theoretical importance from its uniqueness applying the STEM approach to two variables at the same time, which are innovative thinking, mathematical achievement[13-15]. The STEM approach is a topic despite its importance, but it did not meet the attention it deserves, then the research will help enrich the educational library and open horizons for the application of modern teaching approaches. Also, the research reflects the newly applied integrated teaching methods and approaches internationally by presenting an overview of the STEM approach[16]. As for its practical importance, it is derived from the fact that it is field research that applies to teach according to the STEM approach, contributes to drawing the attention of those in charge of the educational process, whether they are curriculum designers, educators, teachers, to follow modern approaches, especially integrative ones. Research tools such as a test to measure the mathematical achievement of fourth-grade students and another to measure innovative thinking in future educational research may be used. The research provides a booklet for the teacher with lessons designed according to the STEM 
approach, and it represents a guide for him to develop more lesson plans in mathematics in the light of this entry[17-19]. At last, but not least, the research provides instructional plans and activities designed according to the STEM approach that may help mathematics and science teachers later in facilitating the teaching of some mathematical and scientific concepts and principles.

\subsection{The research hypothesis and the most important terminology}

1. There are no statistically significant differences at the level of significance $(0.05)$ between the mean scores of the experimental group that studied by applying the STEM approach and the control group that studied in the usual way in the innovative thinking test of scientific fourth-grade students.

2. There are no statistically significant differences at the level of significance $(0.05)$ between the mean scores of the experimental group that studied by applying the STEM entrance and the control group that studied in the usual way in the mathematics achievement test of fourth-grade scientific students.

Search terms: The Integrative Entrance (STEM) is defined as short letters for the four fields of knowledge that are taught to students in schools, and the endowment of science, technology, engineering, and mathematics, which are subjects that need to be learned to integrate, the entrance needs environmental equipment that resembles realworld environments, which helps them connect theoretical knowledge with real-life. It is also defined as an interdisciplinary integrative approach based on the theory of integration between knowledge. It begins with training in investigation, research, and experience; ends with innovation, design processes, and an innovative product[20]. The STEM approach is known in the current research as one of the teaching approaches and based on an integrative approach that works on teaching the four subjects sciences, technology, engineering, engineering, mathematics in a coherent manner, which relies on activities, experimentation to access information. Innovative thinking is defined as a type of divergent thinking that involves recalling previous ideas, making new cognitive links, expanding knowledge, introducing distinct, innovative ideas, meaning that it is a mental interaction that generates new ideas and results. It is also defined as a purposeful and complex mental activity with strong direction from the desire to seek original solutions or outputs that were not present or known before that. The current research defines innovative thinking as complex processes carried out by the individual's mind in order to solve a problem, it searches and investigates and generates many original ideas, which often vary with the diversity of the situation and are distinguished by originality and creativity. Achievement in mathematics, first of all, Academic achievement is defined as the amount that the student obtains in terms of knowledge, information, or skills, and his level of achievement is reflected in his answers to the test prepared to measure this achievement. Achievement in mathematics is also defined as the extent to which students acquire the skills and knowledge aimed at the educational process through the objectives of the educational lesson, by employing those skills and knowledge to solve mathematical problems of mathematics[21, 22, 14]. It is defined in the current research as the amount of information that a student acquires in mathematics 
in a specific period of study that may reach a full academic year, it includes the theories, principles, laws, the various relationships included in the content of the subject and is usually measured by an achievement test.

\section{$2 \quad$ Literature Review}

\subsection{STEM entrance to Science, Technology, Engineering, and Mathematics}

STEM Education has become a top priority for reforming educational processes that adopt integration between academic subjects, as the cries have risen for this over the past two decades, while the STEM approach has proven its effectiveness after its application, especially in the United States of America in particular[23]. Therefore, at the beginning of the discussion about the integrated STEM entrance, we must know what this entrance is, it reflects the first letters of the four words; science, technology, engineering, and mathematics, it is a pedagogical approach that seeks to integrate teaching and learning of the four fields, it needs environments equipped for this purpose, where students practice activities, research projects, workshops, etc. It motivates students and makes learning an enjoyment that pushes students towards reaching a more comprehensive and coherent knowledge and distances them from the usual deaf memorization $[24,25]$. So it is an educational or teaching approach based on the principle of integration between the fields of science, technology, engineering, and mathematics so that they are taught coherently [26, 27]. It is a student-centered approach for learning that integrates science and mathematics and it is an interdisciplinary curriculum in which those disciplines are taught in an interdisciplinary manner and are not bound by a specific discipline with an emphasis on innovation and problem-solving processes using modern technological tools $[28,29]$. It is an entrance to education, in which the natural sciences, engineering, mathematics interact through experimental educational tools and experiments, in which the learner designs products within projects that help him to employ and develop concepts through higher mental skills [30-32]. From the above, the concept of STEM can be summarized as an integral approach for teaching mathematics, science, technology, engineering, as if it were one large discipline that interacts and exchange contents, experiences, and applications with each other, starting with research, thinking and ending with creativity, innovation. We find many names terms in educational literature for it, it is considered an approach, an entrance, or a curriculum. Global trends have emerged towards the application of teaching using the integrated STEM approach based on educational requirements, and this is due to the apparent decline in the level of students in the four subjects, in the different stages of education, and their aversion to mathematics, science for their inability to relate it to reality and represent their education empirically. In addition, societies need to train individuals in more than one scientific field $[33,34]$. There are socio-economic requirements, as the need for employees with many practical and technical skills appeared, which necessitated attention to experiments and practical applications of school materials to face the competitive labor market[35]. The importance of the STEM entrance for teaching mathematics is obvious; the relationship between this entrance and teaching mathematics is 
clear, its letters bear the letter M, which means mathematics. It is a proposed entry for teaching four subjects, including engineering, mathematics, [36, 37] mentions that the entrance to science, technology, engineering, mathematics can leap teaching, learning mathematics at all school levels, because it enables the learner to develop his skills in mathematics in order to reach creativity, outstanding performance, it helps to develop mathematical conceptual understanding through both types of collective, individual learning, including solving problems, numerical sense, using appropriate tools, conducting operations Modeling, simulations, mathematical representations, application of mathematical skills, concepts, interconnections, etc. The National Council of Mathematics Teachers (NCTM) also notes that the importance of the STEM teaching approach in mathematics is due to the fact that it gives mathematics the real meaning within the conduct of engineering designs and problem-solving, and it helps students develop thinking skills and link mathematical skills and applications with their lives [38].The role of the teacher and the learner in applying the STEM approach[39]; as below:

Table 1.

\begin{tabular}{|c|c|c|}
\hline \multirow{8}{*}{$\begin{array}{l}\text { Entrance } \\
\text { STEM } \\
\text { Integrative }\end{array}$} & The role of the teacher & The role of the learner \\
\hline & $\begin{array}{l}\text { Creating an environment for active and effec- } \\
\text { tive learning by directing students and guiding } \\
\text { them towards positive participation in learning } \\
\text { and activities }\end{array}$ & $\begin{array}{l}\text { Active and positive participation in the } \\
\text { learning process and activities }\end{array}$ \\
\hline & $\begin{array}{l}\text { Realizing students 'characteristics and taking } \\
\text { into account their differences }\end{array}$ & $\begin{array}{l}\text { Finding positive solutions to specific situ- } \\
\text { ations and problems }\end{array}$ \\
\hline & $\begin{array}{l}\text { Designing the teaching process in line with } \\
\text { their preparations }\end{array}$ & $\begin{array}{l}\text { Producing new knowledge within the } \\
\text { available knowledge within the scope of } \\
\text { knowledge integration }\end{array}$ \\
\hline & $\begin{array}{l}\text { Encouraging students towards meaningful } \\
\text { learning }\end{array}$ & $\begin{array}{l}\text { Collaborate with peers and communicate } \\
\text { with them positively, and work effectively } \\
\text { within a team }\end{array}$ \\
\hline & $\begin{array}{l}\text { Involve students in brainstorming and thinking } \\
\text { training sessions }\end{array}$ & $\begin{array}{l}\text { Discovery, investigation, research, and } \\
\text { planning for implementation }\end{array}$ \\
\hline & $\begin{array}{l}\text { Raising the self-motivation of the learner to- } \\
\text { wards participation and learning }\end{array}$ & $\begin{array}{l}\text { Evaluation and amendment under the } \\
\text { feedback }\end{array}$ \\
\hline & $\begin{array}{l}\text { To develop himself professionally in the four } \\
\text { disciplines as much as possible }\end{array}$ & $\begin{array}{l}\text { Flexibility with others and accept opinions } \\
\text { and discussions with scientific evidence }\end{array}$ \\
\hline
\end{tabular}

The relationship between teaching with the STEM approach and mathematics and the real change in teaching and learning of the subject emerges from the three axes on which the entry is based, which is changing the visions related to teaching mathematics, science; so that the teaching of mathematics, school science matches the reality of these two subjects, where the failure to present knowledge in the form of real experiences is not reinforced. Questioning, exploring, or not contributing to the understanding of those scientific materials or not deepening the understanding of human experiences is one of the most prominent problems in mathematics and science education. STEM changes the methods of teaching mathematics and school sciences, as students are fully immersed in scientific knowledge, skills, and mental habits, as students search for infor- 
mation for themselves, provide creative solutions to problems and think of sound scientific thinking. It also plays a role in changing the visions and goals of education, so that it becomes aimed towards achieving the comprehension of mathematics and science and their applications by all individuals, and not only for a class of elite[40-44].

\subsection{Innovative thinking}

Scientists differed among themselves on a unified definition of innovative thinking due to the multiplicity of schools of thought of researchers as well as their scientific interests. The word "creativity" is originally a word derived from the Latin "creare" meaning creating or inventing something, so innovation here is meant to produce something new that was not produced before that. It is an intellectual activity in which the student becomes sensitive to problems, able to identify the deficiencies, gaps of information with the ability to formulate questions, formulate hypotheses about those problems, and test the validity of solutions so that he can reach original solutions that are not repeated, thinking characterized by the emergence of abundant, varied, new, original ideas[45-48]. The research relies on innovative thinking skills appropriate to mathematics, developed by Glyphord and Torrance, namely:

1. Fluency: It is the ability to generate the largest number of ideas, with those ideas related to the topic, and these ideas may be represented in the form of terms, expressions, or drawings $[49,50]$.

2. Flexibility: It is the ability to produce ideas in a rapid and varied manner as the individual changes his thinking orientations in a way that suits the situation or the problem at hand and according to the influences as these influences are characterized by a variable nature $[51,52]$.

3. Originality: It is the use of thinking in an unusual way, the response that is not familiar and unique, in which ideas flow in a free way to obtain many ideas in a short period [53].

4. Relationships: It means the student's ability to create relationships between what he learns, it usually defines similarity, symmetry, and difference[54].

Innovative thinking is the most prominent goal in the principles of the integrated STEM approach; as among the objectives of this approach is to seek to provide students with skills, the most important of which are science skills, mathematical skills, investigation skills, creative problem-solving, technological, programming skills, and higher thinking skills, on top of which is innovative (creative thinking), with the students' use of logical reasoning in creativity processes $[55,56]$.

\subsection{Achievement in mathematics}

Achievement considered as the ability of the learners to understand, assimilate the study materials and their contents through the learner's perception of the relationships between the information included in the contents of the course, the facts and concepts that he extracts from them that will be subsequently reflected on his performance in the 
tests that measure this, whether they are written or oral tests, at any time determined for their conduct. As for mathematics achievement, it is the results of what students learn from the elements of mathematics, it is considered an indicator of the success of one of the teaching strategy that was followed in learning, in a certain period and is usually measured by an achievement test prepared for this purpose [57, 58]. Some factors affect students 'academic achievement, such as ways of thinking, habits of mind, motivation, self-concept, in addition to dealing with information, obtaining it, making decisions about it, and these factors may be affected by external factors that contribute to its development, including teaching methods and strategies for developing these Aspects[59]. The researchers add that measuring academic achievement determines the success of teaching methods, the effectiveness of the teaching strategies used in the teaching process, the positive impact of the teaching approaches used, the success and distinction of the teacher, the success of the educational and school system as a whole.

\section{Research Methodology and Procedures}

The research was based on the quasi-experimental method. The research design was experimental from two groups, one of them is control and the other is experimental, as shown in Table (1). The research community identified fourth-grade scientific students in the Al-Intisar Girls' Preparatory School in the First Rusafa District. The research sample was chosen intentionally, as it was represented by a group of students of the fourth scientific grade in Al-Intisar Preparatory School for Girls, numbering (32) students, it was divided into two groups, the control, which studied in the traditional way numbered (16), the experimental one that studied using the STEM entrance, their number (16) students also. As for the procedures for controlling parity of the research sample, the two research groups were rewarded with several variables (previous knowledge, chronological age, previous achievement in mathematics, innovative thinking test). These variables were determined by obtaining information on chronological age, previous achievement in mathematics from records. As for the previous knowledge, the students 'grades were obtained after testing them, examining their answers, determining the grades of each of them. When a comparison is made between the mean scores of the experimental and control research groups using the t-test for two independent samples, it was found that the calculated $t$ value is less than the tabular value of the variables, which means that the two groups are equivalent to the mentioned variables.

Table 2. The experimental design of the research

\begin{tabular}{|l|l|l|l|}
\hline \multicolumn{1}{|c|}{ Groups } & \multicolumn{1}{|c|}{ Previous application } & \multicolumn{1}{c|}{ The experience } & \multicolumn{1}{c|}{ Post application } \\
\hline The experimental group & $\begin{array}{l}\text { The pre-application for } \\
\text { the mathematical } \\
\text { achievement test and the } \\
\text { innovative thinking test }\end{array}$ & $\begin{array}{l}\text { Teaching using a STEM } \\
\text { entrance }\end{array}$ & $\begin{array}{l}\text { Teaching by the } \\
\text { traditional way }\end{array}$ \\
\hline The control group & $\begin{array}{l}\text { Post application of } \\
\text { test, logical. }\end{array}$ \\
\hline
\end{tabular}

The research tools are taught booklet using STEM integrative science, technology, engineering, mathematics, achievement test in mathematics (in the second semester of the fourth-grade mathematics science book, equations, and inequalities), innovative 
thinking test. The preparation of the research tools required analyzing the content of the second semester to determine the elements of the mathematical content that it includes, as well as preparing a table of specifications for the objectives of the teaching unit. Preparing a form for content analysis consisting of a table containing the unit's topics and their skills, concepts, generalizations, and laws. To ensure the validity of the analysis, the analysis form was presented with a copy of the prescribed chapter of the book to several arbitrators with experience and competence in measurement and evaluation, in methods of teaching mathematics, the analysis was adopted in the light of the opinions of the referees. Then finding the stability of the analysis through unit analysis, then repeat the analysis after three weeks, where the Holste equation was used to calculate the reliability coefficient, the test reliability values were high, indicating the reliability of the analysis.

\subsection{Set up search tools}

1. To prepare a teaching booklet by applying the STEM entrance, the important objectives were defined in the second chapter (equations and inequalities), analyzing the unit content, reviewing the literature and previous studies to benefit from them. The guide included the educational and philosophical foundations on which the STEM entrance is based, a list of the lessons included in the unit, the teaching aids, and tools used, the time plan needed to implement the unit, instructions for the teacher, the second-semester lesson plan in the book (equations and inequalities) according to the entry. The guide was presented to a group of experts specializing in curricula and methods of teaching mathematics to obtain their opinions, suggestions, and observations. The researchers have reached the final proof based on the opinions of experts.

2. Achievement test: The test aims to measure the mathematical achievement of the fourth-grade students of the experimental group that studied according to the STEM entrance, the control group that studied according to the usual method. After reviewing the previous studies related to the subject of this research, especially those that included tests as a tool for them, the achievement test was prepared to measure students 'achievement of concepts, theories, laws, and mathematical skills contained in the second chapter (Equations and inequalities) in my fourth-grade mathematics textbook. Research before applying the experiment. The same test was also adopted to be a post-test to measure achievement. By referring to the textbook for the mathematics curriculum and the teacher's guide, extracting the main and subconcepts, by which the general and special goals are achieved, the second chapter (equations and inequalities) was chosen, then a table of specifications was prepared and the relative weights were determined based on the number of objectives specified in the course, a list of concepts and skills was drawn up. the mathematical principles that student's study in the content of the chosen unit by designing a form that contains unit lessons and educational objectives formulated in each lesson of the unit with the classification of goals according to Bloom's classification then presented to the expert referees, where the total number of educational objectives became in its final form of the table of specifications. Objectives (40) goals and then 
drafting the test paragraphs so that they cover all the concepts, skills, principles contained in the content of the book subject of the experiment. Since (40) questions were formulated covering all the objectives, all the items of the test were in the form of multiple choice. The test was presented in its preliminary form to some arbitrators to verify the indications of the apparent validity of the test by using the validity of the arbitrators, and the arbitrators were chosen from among those with experience, and competence in the final measurement and evaluation, and the test methods were taken. The test time was calculated by monitoring the time of each member of the exploratory sample for the test necessary to complete the test completely, and then calculating the average time for all, and it was found that the appropriate period for completing the test is (60 minutes) that includes the duration of reading the instructions. The reliability of the test was calculated by relying on the Cronbach alpha coefficient and the reliability coefficient was good.

3. The innovative thinking test: To prepare it in mathematics for the students of scientific fourth class the goal has been determined, which is to measure the innovative thinking skills for them (before and after) that is, before the application of teaching by the STEM entrance to the experimental group or the usual teaching of the control group. After reviewing the relevant literature and research, a list of innovative thinking skills was proposed, appropriate to the age of students of scientific fourth class, as well as suitable for measuring creative thinking in line with the subject of mathematics. Skills in fluency, flexibility, originality, and relationships. To formulate the paragraphs, a style of essay questions with short answers was adopted, to measure students' ability of innovative thinking skills. It was taken into account when formulating the age group of students, the comprehensiveness of the questions to the content of the unit of study, and that the answers to the questions were short and be open-ended, that is, they can bear more than one answer. For the validity of the test, it was presented to a group of referees in the field of cognitive psychology; methods of teaching mathematics to obtain their opinions on the suitability of the test items for the research sample and the test, the paragraphs have been amended in light of these opinions. The test was applied in its initial form to a group of fourthgrade scientific students in Al-Intisar Prep for Girls. The test reliability was calculated using Pearson's correlation coefficient, reaching (0.82), which indicates the test's stability with a high degree. The appropriate time to answer the test was calculated through the exploratory experiment, as it was found that the appropriate time to answer the test is approximately an hour, including reading the instructions. Students were given scores for each complete and correct answer of each of the test questions, which are (21) questions, then calculating each answer that takes a path equivalent to half the answer by one degree, as for answers that are completely out of correctness, they are counted at zero, and accordingly, the total test score becomes (42) marks. It was the final image of the test.

4. To apply the research tools, there is the pre-application of the research tools, namely the innovative thinking skills test and the mathematics achievement test, on the selected research sample, taking into account the introduction of students to the research tools. And the research experience, as the control group, was taught in the usual and experimental way by applying the STEM entrance; in the classroom, with 
the help of the math teacher assigned to the class and his help with the guide prepared by the two researchers, the teaching period for the prescribed unit lasted five weeks, then the post-application of the tests, as the prepared tests were applied again to the students after applying the experiment.

\section{$4 \quad$ Results and Discussion}

\subsection{Display search results}

1. To test the validity of the first hypothesis of the research, verify it, the Innovative Thinking test was applied in dimension to the two groups, and the value of (T) was calculated to identify the significance of the differences between the experimental and the control in the test, the $\mathrm{T}$ value was calculated to identify the significance of the differences between the pre and post measurement of the experimental group in the same test. Where it appears that there are statistically significant differences at the level of significance (0.05) between the mean of the experimental scores that were studied according to the STEM approach and the control in the post-measurement of the innovative thinking test in favor of the experimental group, as the calculated value was greater than the tabulated value, which means rejecting the hypothesis, which indicates The level of innovative thinking skills improved among students of the fourth grade of scientific experimental personnel, for whom the teaching was applied by applying the STEM approach, the degree of freedom, and it becomes clear that the size of the effect is very large, according to Cohen's classification. This indicates that the independent variable STEM input has an effect on the first dependent variable (innovative thinking) or has the effect of changing the level of innovative thinking skills of the members of the experimental group for research, and this is evident in Tables (2) and (3).

Table 3. The value of the (T) test and the level of statistical significance for the differences between the experimental and control group in the innovative thinking test

\begin{tabular}{|l|c|c|c|c|c|c|c|l|}
\hline \multicolumn{1}{|c|}{ Groups } & No. & Mean & $\begin{array}{c}\text { Standard } \\
\text { Deviation }\end{array}$ & $\begin{array}{c}\text { t-Test } \\
\text { Tabular }\end{array}$ & $\begin{array}{c}\text { t-Test } \\
\text { Calcu- } \\
\text { lated }\end{array}$ & $\begin{array}{c}\text { Degree of } \\
\text { Freedom }\end{array}$ & $\begin{array}{c}\text { Significance } \\
\text { Level }\end{array}$ & $\begin{array}{c}\text { Statsignifi- } \\
\text { cance Level }\end{array}$ \\
\hline Experimental & 16 & 40.7 & 7.19 & 2 & 4.42 & 84 & 0.05 & Significant \\
\hline Control & 16 & 36 & 7.09 & 2 & 42 & \\
\hline
\end{tabular}

Table 4. The magnitude of the impact of STEM on innovative thinking

\begin{tabular}{|l|l|c|c|l|}
\hline Independent Variable & Dependent Variable & The value of d & $\mathbf{n ~ 2}$ & Effective size level \\
\hline $\begin{array}{l}\text { Teaching is according to } \\
\text { STEM }\end{array}$ & Innovative thinking & 1.091 & 1.089 & Very big \\
\hline
\end{tabular}

2. In order to test the validity of the second hypothesis for the research and verify it, the mathematical achievement test was applied in dimension to the experimental group and the control group, and the value of $(\mathrm{t})$ was calculated to identify the significance of the differences between the experimental and control group in the 
achievement test, and the value of $(t)$ was calculated to identify the significance of the differences between the pre-measurement. And the posture for the second experimental group in the test and is illustrated in Table (4). Through it, it appears that there are statistically significant differences at the level of significance $(0.05)$ between the mean of the experimental scores that were studied according to the STEM entrance and the control in the post-measurement of the achievement test in mathematics in favor of the experimental. As the calculated value of $\mathrm{T}$ is greater than the tabular $\mathrm{T}$ value, which means that the hypothesis is rejected. This indicates an increase in the scientific achievement of fourth-grade students in mathematics among the members of the experimental group, who were taught by following the integrated approach to science, technology, engineering, and mathematics (STEM). The results also indicate that there is a positive effect of teaching according to this approach on student achievement, to know the size of the effect, the formula for the directed effect size complementing the statistical significance was applied in light of the values of the (t) test, the degree of freedom, it was found that the size of the effect is very large, according to Cohen's classification. This indicates that the independent variable STEM input has an effect on the second dependent variable (academic achievement in mathematics) or has an effect on raising levels of achievement (knowledge and understanding, application, recollection, higher thinking skills) of the members of the experimental group for the research, as in the tables below.

Table 5. The value of the (T) test and the level of statistical significance for the differences between the experimental and control group in the innovative thinking test

\begin{tabular}{|l|c|c|c|c|c|c|c|c|}
\hline \multicolumn{1}{|c|}{ Groups } & No. & Mean & $\begin{array}{c}\text { Standard } \\
\text { Deviation }\end{array}$ & $\begin{array}{c}\text { t-Test } \\
\text { Tabular }\end{array}$ & $\begin{array}{c}\text { t-Test Cal- } \\
\text { culated }\end{array}$ & $\begin{array}{c}\text { Degree of } \\
\text { Freedom }\end{array}$ & $\begin{array}{c}\text { Significance } \\
\text { Level }\end{array}$ & $\begin{array}{c}\text { Statsignifi- } \\
\text { cance Level }\end{array}$ \\
\hline Experimental & 16 & 41 & 6.97 & 1.95 & 3.89 & 81 & 0.05 & Significant \\
\hline Control & 16 & 32 & 6.1 & 1.95 & & & \\
\hline
\end{tabular}

Table 6. The magnitude of the effect of STEM on mathematical achievement

\begin{tabular}{|l|c|c|c|l|}
\hline Independent Variable & Dependent Variable & $\mathbf{n ~ 2}$ & The value of d & Effective size level \\
\hline $\begin{array}{l}\text { Teaching is according to } \\
\text { STEM }\end{array}$ & Mathematical achievement & 0.187 & 1.092 & Very big \\
\hline
\end{tabular}

\subsection{Interpretation of Results}

1. The findings of the two researchers through the statistical treatment of the first hypothesis related to the effect of the STEM approach on innovative thinking among students is evident from the non-acceptance of the hypothesis as it has been proven that there are statistically significant differences between students in favor of the experimental group, which indicates the effect of the positive approach on the development of innovative thinking skills among students and attributing That is because one of the teaching principles in the STEM entrance is the phrase (from think to thing), which means transferring ideas into tangible products, a principle that leaves no room for doubt that this approach is based on innovation, creativity, and 
then it encourages students to innovate, thus that students, while learning through the integrated STEM entrance, connect the four fields of science, technology, engineering, mathematics in an atmosphere of generating new ideas, creating original works that do not exist before, through experimentation, practical practice, which is one of the innovative thinking skills. The strategies that are employed within the STEM approach, including cooperative learning, brainstorming and others, are strategies that work to involve students in the educational process, link experiences with theories, principles, and laws of mathematics, all of which develop students' innovative thinking skills, especially fluency, flexibility, and originality. As for the skill of relationships, the STEM approach is one of the most appropriate approaches to develop this skill, as it helps students to find the relationship between theoretical; life matters; the relationship between subjects and some of them within the same subject or across the four disciplines, the student must employ various relationships, equations, so on. Within the learning of these materials, especially that the STEM entrance deals with them as if they were one major specialty, which helps to develop the skill of finding the relationship between symmetry, similarity, and others

2. Results related to the effect of the STEM approach on mathematical achievement: It is evident from the results obtained through the statistical treatment of the second hypothesis related to the effect of the STEM entrance on mathematical achievement among students. The hypothesis is not accepted as it has been proven that there are statistically significant differences Among female students for the benefit of the experimental group, which indicates the effect of the positive approach on raising the level of achievement in mathematics among fourth-grade students of science, due to the fact that the integrative nature of the STEM entrance increases students 'acquisition of mathematical concepts in a smooth, accessible manner, where students see themselves, work with their hands in applying mathematics in other subjects Science; for example; which leads to a high level of mathematical achievement for them. The use of the STEM approach in teaching made learning mathematics meaningful learning in which the relationships, linkages between previous, new knowledge are understood, which enhances students' comprehension and thus increases their academic achievement. Linking mathematics learning with other subjects, such as various technologies, science, engineering designs, creates an atmosphere of enthusiasm that attracts students to mathematics and improves their motivation to learn and then increases achievement. The STEM entrance transforms abstract mathematical concepts into concrete experiences, practices, and applications so that the concepts take root in the minds of students and last for a longer period, thus improving the level of mathematics achievement. The evaluation takes place within the STEM entrance in several ways under the name of alternative evaluation, such as achievement files and others, and the feedback provided to students within the assessments is a reason for improving their performance and thus their academic achievement. The fact that work and learning within projects in light of the STEM integration approach in the form of work teams in which students exchange views, ideas is one of the reasons for the survival of information and the stability of mathematics laws without the need for deaf memorization. 


\section{Conclusion}

1. The Entrance (STEM) has clear efficacy in developing students' innovative thinking skills.

2. The (STEM) approach works to raise students 'achievement in mathematics.

3 . Teaching with the above approach creates an atmosphere of enthusiasm that attracts students to mathematics; improves their motivation for learning, creativity, and innovation.

4. Mathematics books should contain attitudes, experiences, and activities that develop the creative skills of middle school students

5. Holding training programs for service teachers and student teachers to raise awareness of the entrance, its principles, and the teacher's role in it.

6. Conducting other future studies that study the effectiveness of the STEM approach with the use of other variables such as sports communication, twenty-first-century skills, and others.

\section{References}

[1] K. Devlin, Mathematics education for a new era: Video games as a medium for learning. CRC Press, 2011.

[2] I. A. Mendes and C. A. da Silva, "Problematization and research as a method of teaching Mathematics," International Electronic Journal of Mathematics Education, vol. 13, no. 2, pp. 41-55, 2018.

[3] C. K. Baker and T. Galanti, "Integrating STEM in elementary classrooms using model-eliciting activities: responsive professional development for mathematics coaches and teachers," International Journal of STEM Education, vol. 4, no. 1, pp. 1-15, 2017. https://doi.org/10. 1186/s40594-017-0066-3

[4] G.-J. Hwang, S.-Y. Wang, and C.-L. J. C. Lai, "Effects of a social regulation-based online learning framework on students' learning achievements and behaviors in mathematics," Computers \& Education, vol. 160, p. 104031, 2021. https://doi.org/10.1016/j.compedu. 2020.104031

[5] B. Tanujaya, J. Mumu, and G. Margono, "The Relationship between Higher Order Thinking Skills and Academic Performance of Student in Mathematics Instruction," International Education Studies, vol. 10, no. 11, pp. 78-85, 2017. https://doi.org/10.5539/ies.v10n11p78

[6] C. McGuinness, from thinking skills to thinking classrooms: A review and evaluation of approaches for developing pupils' thinking. Department for Education and Employment London, 1999.

[7] W. Conklin, Higher-order thinking skills to develop 21st century learners. Teacher Created Materials, 2011.

[8] D. K. Al-Malah, H. H. Jinah Salim "Enhancement of educational services by using the internet of things applications for talent and intelligent schools," Periodicals of Engineering and Natural Sciences (PEN), vol. 8, no. 4, pp. 2358-2366, 2020.

[9] B. H. Majeed, "The Impact of Reflexive Learning Strategy on Mathematics Achievement by First Intermediate Class Students And Their Attitudes Towards E-Learning," Turkish Journal of Computer and Mathematics Education (TURCOMAT), vol. 12, no. 7, pp. 32713277, 2021. 
[10] L. F. Jawad, "Levels of Geometrical Thinking of The Students of Mathematics Department in Basic Education College at AL-Mustansiriyah University, "Journal of Educational and Psychological Researches, vol. 8, no. 31, 2011.

[11] D. L. Ball and H. Bass, "Toward a practice-based theory of mathematical knowledge for teaching," in Proceedings of the 2002 annual meeting of the Canadian Mathematics Education Study Group, 2002, pp. 3-14: Citeseer.

[12] A. J. Lee, Development and Education, "A Forgotten Underrepresented Group: Students with Disabilities' Entrance into STEM Fields," International Journal of Disability, Development and Education, pp. 1-18, 2020. https://doi.org/10.1080/1034912x.2020.1767762

[13] A. Bicer, Y. Lee, C. Perihan, M. M. Capraro, and R. M. Capraro, "Considering mathematical creative self-efficacy with problem posing as a measure of mathematical creativity," Educational Studies in Mathematics, vol. 105, no. 3, pp. 457-485, 2020. https://doi.org/10.1007/ s10649-020-09995-8

[14] B. H. Majeed, "Mathematical Logical Intelligence and its Relationship with Achievement among College of Education Students in Baghdad Governorate," Nasaq, vol. 1, no. 2, 2014.

[15] L. Jawad, "Learning Styles according to the Model of Felder \& Silverman and its Relationship with Mathematical Self-perceived Efficacy to Students of the College of Education for Pure Sciences-Ibn Al-Haitham," International Journal of Science and Research, vol. 6, no. 4, pp. 686-693, 2015.

[16] K. J. Pugh, Transformative Science Education: Change how Your Students Experience the World. Teachers College Press, 2020.

[17] M. A. Madhia and M. H. f. Jasimb, "Educational Learning Design Based on the Stem Approach Entrance and Its Impact on the Scientific Development of the First Grade Mediterranean Students," vol. 14, no. 10, 2020.

[18] S. A. Aloraini, "Development of Mathematics Teacher's Preparation Programs in the Light of STEM Education," Journal of Education and Training Studies, vol. 8, no. 4, pp. 10-26, 2020.https://doi.org/10.11114/jets.v8i4.4707

[19] D. K. Abdul-Rahman, S. I. Hamed, and H. ALRikabi, "The Interactive Role Using the Mozabook Digital Education Application and its Effect on Enhancing the Performance of eLearning," International Journal of Emerging Technologies in Learning (iJET), vol. 15, no. 20, pp. 21-41, 2020. https://doi.org/10.3991/ijet.v15i20.17101

[20] B. H. Majeed, "The Relationship Between Conceptual Knowledge and Procedural Knowledge among Students of the Mathematics Department at the Faculty of Education for Pure Sciences/Ibn AlHaitham, University of Baghdad," International Journal of Innovation, Creativity and Change, vol. 12, no. 4, pp. 333-346, 2020. https://doi.org/10.21275/ art20178962

[21] S. Psycharis and M. J. Kallia, "The effects of computer programming on high school students' reasoning skills and mathematical self-efficacy and problem solving," Instructional Science, vol. 45, no. 5, pp. 583-602, 2017. https://doi.org/10.1007/s11251-017-9421-5

[22] S. J. Saygıl1, "Examining the problem-solving skills and the strategies used by high school students in solving non-routine problems," E-International Journal of Educational Research, vol. 8, no. 2, pp. 91-114, 2017.

[23] L. F. Jawad, B. H. Majeed, and H. T. ALRikabi, "The Impact of CATs on Mathematical Thinking and Logical Thinking Among Fourth-Class Scientific Students," International Journal of Emerging Technologies in Learning (iJET), vol. 16, no. 10, 2021. https://doi.org/10.3991/ijet.v16i10.22515

[24] A. Ekmekci, A. Sahin, O. Gulacar, and K. Almus, "High school students' semantic networks of scientific method in an international science olympiad context," EURASIA Journal of 
Mathematics, Science and Technology Education, vol. 14, no. 10, p. em1604, 2018. https://doi.org/10.29333/ejmste/93677

[25] D. Abdul-Rahman, I ALjazeary, H. Salim Alrikabi, and H. A. Mutar, "Cloud Computing and its Impact on Online Education," IOP Conference Series: Materials Science and Engineering, vol. 1094, p. 012024, 2021. https://doi.org/10.1088/1757-899x/1094/1/012024

[26] A. H. Alghamdi and L. Li, "Teachers' Continuing Professional Development Programmes in the Kingdom of Saudi Arabia," Online Submission,2011.

[27] A. Salah., R. S. Khairy, H. ALRikabi2, "The Detection of Counterfeit Banknotes Using Ensemble Learning Techniques of AdaBoost and Voting," International Journal of Intelligent Engineering and Systems, vol. 14, no. 1, pp. 326-339, 2021. https://doi.org/10.22266/ ijies2021.0228.31

[28] G. L. Huah, "Considering the Fourth Quadrant Learning: Facilitating Learners Towards Acceptance of Blended Learning," in Advancing Innovation and Sustainable Outcomes in International Graduate Education: IGI Global, 2021, pp. 209-237. https://doi.org/10.4018/ 978-1-7998-5514-9.ch013

[29] M. Al-dabag, H. S. ALRikabi, and R. Al-Nima, "Anticipating Atrial Fibrillation Signal Using Efficient Algorithm," International Journal of Online and Biomedical Engineering (iJOE), vol. 17, no. 2, pp. 106-120, 2021. https://doi.org/10.3991/ijoe.v17i02.19183

[30] C. V. McDonald, "STEM Education: A review of the contribution of the disciplines of science, technology, engineering and mathematics," Science Education International, vol. 27, no. 4, pp. 530-569, 2016.

[31] F. J. Alrabai, "Factors underlying low achievement of Saudi EFL learners," International Journal of English Linguistics, vol. 6, no. 3, pp. 21-37, 2016. https://doi.org/10.5539/ ijel.v6n3p21

[32] A. S. Hussein, R. S. Khairy, S. M. Najeeb, and H. T. J. ALRikabi, "Credit Card Fraud Detection Using Fuzzy Rough Nearest Neighbor and Sequential Minimal Optimization with Logistic Regression," International Journal of Interactive Mobile Technologies, vol. 15, no. 5, 2021. https://doi.org/10.3991/ijim.v15i05.17173

[33] B. Yildirim and C. J. Türk, "Opinions of Secondary School Science and Mathematics Teachers on STEM Education," World Journal on Educational Technology: Current Issues, vol. 10, no. 1, pp. 52-60, 2018. https://doi.org/10.18844/wjet.v10i1.3120

[34] N. S. Alseelawi, E. K. Adnan, H. T. Hazim, H. Alrikabi, and K. Nasser, "Design and Implementation of an E-learning Platform Using N-Tier Architecture," international Journal of Interactive Mobile Technologies, vol. 14, no. 6, pp. 171-185, 2020. https://doi.org/10. 3991/ijim.v14i06.14005

[35] S. Blackley, R. Sheffield, and R. J. Koul, "Using a Makerspace approach to engage Indonesian primary students with STEM," Issues in Educational Research, vol. 28, no. 1, pp. 18 42, 2018.

[36] D. J. Tsybulsky, "Students meet authentic science: the valence and foci of experiences reported by high-school biology students regarding their participation in a science outreach programme," International Journal of Science Education, vol. 41, no. 5, pp. 567-585, 2019. https://doi.org/10.1080/09500693.2019.1570380

[37] H. A. Naman, N. A. Hussein, M. L. Al-dabag, H. Alrikabi, "Encryption System for Hiding Information Based on Internet of Things," International Journal of Interactive Mobile Technologies (iJIM), vol. 15, no. 2, 2021. https://doi.org/10.3991/ijim.v15i02.19869

[38] L. M. Hefty, "STEM gives meaning to mathematics," Teaching Children Mathematics, vol. 21, no. 7, pp. 422-429, 2015. https://doi.org/10.5951/teacchilmath.21.7.0422

[39] S. S. Guzey, T. J. Moore, and M. J. Harwell, "Building up STEM: An analysis of teacherdeveloped engineering design-based STEM integration curricular materials," Journal of Pre- 
College Engineering Education Research (J-PEER), vol. 6, no. 1, p. 2, 2016. https://doi.org/10.7771/2157-9288.1129

[40] T. M. Leonard, Encyclopedia of the developing world. Routledge, 2013.

[41] R. A. Madani, "Teacher Perceptions of the New Mathematics and Science Curriculum: A Step Towards STEM Implementation in Saudi Arabia," The British University in Dubai (BUiD), 2017. Result score too low

[42] A. Alaidi, O. Yahya, and H. Alrikabi, "Using Modern Education Technique in Wasit University," International Journal of Interactive Mobile Technologies, vol. 14, no. 6, pp. 82-94, 2020. https://doi.org/10.3991/ijim.v14i06.11539

[43] R. M. Al_airaji, I. A. Aljazaery, S. K. Al_dulaimi, and H. T. S. Alrikabi, "Generation of high dynamic range for enhancing the panorama environment," Bulletin of Electrical Engineering and Informatics, Article vol. 10, no. 1, pp. 138-147, 2021.https://doi.org/10.11591/ eei.v10i1.2362

[44] L. F. Jawad, "The Impact of Innovative Matrix Strategy and The Problem Tree Strategy On The Mathematical Proficiency Of Intermediate Grade Female Students," Turkish Journal of Computer and Mathematics Education (TURCOMAT), vol. 12, no. 7, pp. 3296-3305, 2021.

[45] T. S. Al-Shabibi, M. A.-K. Al-Ayasra, "Effectiveness of the flipped classroom strategy in learning outcomes (bibliometric study)," International Journal of Learning, Teaching and Educational Research, vol. 18, no. 3, pp. 96-127, 2019. https://doi.org/10.26803/ijlter.18.3.6

[46] B. A. Al-Khatib, "The effect of using brainstorming strategy in developing creative problemsolving skills among female students in Princess Alia University College," American International Journal of Contemporary Research, vol. 2, no. 10, pp. 29-38, 2012.

[47] S. M. M. Najeeb, H. T. Salim, and S. M. Ali, "Finding the discriminative frequencies of motor electroencephalography signal using genetic algorithm," TELKOMNIKA, vol. 19, no. 1, pp. 285-291, 2021. https://doi.org/10.12928/telkomnika.v19i1.17884

[48] B. Mohammed, R. Chisab, and H. Alrikabi, "Efficient RTS and CTS Mechanism Which Save Time and System Resources," international Journal of Interactive Mobile Technologies, vol. 14, no. 4, pp. 204-211, 2020. https://doi.org/10.3991/ijim.v14i04.13243

[49] A. FIRAT, "A Study on Young Learners' Attitudes Towards learning English," Master Thesis, Unpublished. Turkey: Adana: Çukurova University, 2009.

[50] L. U. DeWyngaert, "What Makes a Successful Reader? an Examination of Creative Thinking, Analytic Thinking and Executive Functioning," University of Maryland, Baltimore County, 2016

[51] H. M. Al-Hafidh, "Effect of Using Scientific Stations Strategy in Developing Deductive Thinking of Intermediate School Students in General Sciences," International Journal of Early Childhood Special Education, vol. 12, no. 2, 2020. https://doi.org/10.9756/intjecse/v12i2.201054

[52] A. E. Wróbel, P. Cash, and C. J. Lomberg, "Pro-active neutrality: The key to understanding creative facilitation," Creativity and Innovation Management, vol. 29, no. 3, pp. 424-437, 2020.https://doi.org/10.1111/caim.12372

[53] R. Ackerman and V. A. Thompson, "Meta-reasoning: Monitoring and control of thinking and reasoning," vol. 21, no. 8, pp. 607-617, 2017. https://doi.org/10.1016/j.tics. 2017.05.004

[54] D. J. Ambrose, "Interdisciplinary invigoration of creativity studies," The Journal of Creative Behavior, vol. 51, no. 4, pp. 348-351, 2017. https://doi.org/10.1002/jocb.205

[55] C. J. Fong, Y. Kim, C. W. Davis, T. Hoang, and Y. W. Kim, "A meta-analysis on critical thinking and community college student achievement," Thinking Skills and Creativity, vol. 26, pp. 71-83, 2017. https://doi.org/10.1016/j.tsc.2017.06.002

[56] B. H. Majeed, L. F. Jawad, H. Alrikabi, "Tactical Thinking and its Relationship with Solving Mathematical Problems Among Mathematics Department Students," International Journal 
of Emerging Technologies in Learning (iJET), vol. 16, no. 9, 2021. https://doi.org/10.3991/ ijet.v16i09.22203

[57] X. Ma and N. Kishor, "Assessing the relationship between attitude toward mathematics and achievement in mathematics: A meta-analysis," Journal for research in mathematics education, pp. 26-47, 1997. https://doi.org/10.2307/749662

[58] L. F. Jawad, M. K. Raheem, and B. H. Majeed, "The Effectiveness of Educational Pillars Based on Vygotsky's Theory in Achievement and Information Processing Among First Intermediate Class Students," International Journal of Emerging Technologies in Learning, vol. 16, no. 12, pp. 246-262, 2021. https://doi.org/10.3991/ijet.v16i12.23181

[59] A. Hofstein and V. N. Lunetta, "The role of the laboratory in science teaching: Neglected aspects of research," Review of educational research, vol. 52, no. 2, pp. 201-217, 1982. https://doi.org/10.3102/00346543052002201

\section{$7 \quad$ Authors}

Lina Fouad Jawad, She is presently Assistant Professor Dr., and one of the faculty members in the College of Education for Pure Sciences / Ibn Al-Haytham, Computer Department, University of Baghdad, Iraq. Her current research interests include methods of teaching and strategies, E-learning, Educational Technology. mail: lina.f.j@ihcoedu.uobaghdad.edu.iq

Ban Hassan Majeed, She is presently the lecturer and one of the faculty of the computer department, College of Education for Pure Sciences / Ibn Al- Haitham, University of Baghdad, Iraq. Her current research interests include methods of teaching mathematics, thinking, thinking skills, multiple Intelligences, Educational Technology, Technological innovations. Email: ban.h.m@ihcoedu.uobaghdad.edu.iq

Haider Th. Salim ALRikabi: - He is presently Asst. Prof and one of the faculty

College of Engineering, Electrical Engineering Department, Wasit University in Al Kut, Wasit, Iraq. He received his B.Sc. degree in Electrical Engineering in 2006 from the Al Mustansiriya University in Baghdad, Iraq. His M.Sc. degree in Electrical Engineering focusing on Communications Systems from California State University/Fullerton, the USA in 2014. His current research interests include Communications systems with the mobile generation, Control systems, Intelligent Technologies, Smart Cities, and the Internet of Things (IoT), Renewable Energy. Al Kut city - Hay ALRa- bee, Wasit, Iraq. E-mail: hdhiyab@uowasit.edu.iq. The number of articles in national databases -10 , and the number of articles in international database-30.

Article submitted 2021-05-22. Resubmitted 2021-06-22. Final acceptance 2021-06-23. Final version published as submitted by the authors. 